\title{
Presidential Candidacy Threshold and Presidentialism Affirmation in Indonesia
}

\author{
Titon Slamet Kurnia* \\ DOI: https://doi.org/10.22304/pjih.v7n3.a4
}

Submitted: September 28, 2020 | Accepted: November 30, 2020

\begin{abstract}
This study discusses the constitutionality of presidential candidacy threshold, particularly related to the principle of presidentialism. This study argues that the threshold is unconstitutional because it does not reflect the principle of presidentialism. The principle emphasizes executive and legislative prescriptions that should be independent of each other. Supporting the current threshold, the Constitutional Court proposes a rationale that the threshold aims to strengthen presidentialism in Indonesia. The current threshold is believed can give the elected president adequate political support in parliament. In fact, the idea is not factually and juridically correct. An elected president can govern effectively without significant institutional obstacle, although the President does not gain support of majority political power in the parliament. On that basis, it is necessary to amend Article 6A paragraph (2) of the 1945 Constitution so that the implementation of presidential system can be more consistent. Political parties should not be given monopolistic power to bear the presidential and vice-presidential candidates. The system should also accommodate the possibility of independent presidential and vice-presidential candidates, separating the line of political parties. Such constitutional provisions are expected to annul the presidential nomination threshold.
\end{abstract}

Keywords: constitutionality, presidential candidacy threshold, presidentialism.

\section{Ambang Batas Pencalonan Presiden dan Penegasan Presidensialisme di Indonesia}

\begin{abstract}
Abstrak
Artikel ini mendiskusikan isu hukum apakah ambang batas pencalonan presiden konstitusional, khususnya dikaitkan dengan asas presidensialisme. Artikel ini berargumen bahwa ambang batas pencalonan presiden inkonstitusional karena tidak mencerminkan asas presidensialisme yang mengandung preskripsi eksekutif dan legislatif saling tidak bergantung. Alasan Mahkamah Konstitusi bahwa ambang batas pencalonan presiden konstitusional dalam rangka penguatan presidensialisme di Indonesia, supaya presiden terpilih nantinya mendapatkan dukungan politik yang memadai di parlemen, tidak tepat baik secara faktual maupun secara yuridis. Walau tidak didukung oleh kekuatan politik mayoritas di parlemen, sesuai asas presidensialisme, hal itu bukan hambatan institusional
\end{abstract}

PADJADJARAN Journal of Law Vol. 7 Number 3 Year 2020 [ISSN 2460-1543] [ISSN 2442-9325]

* Lecturer of the Law Faculty, Universitas Kristen Satya Wacana, Jalan Diponegoro 52-60, Salatiga, 50711, S.H. (Universitas Kristen Satya Wacana Salatiga), M.H. (Universitas Airlangga), Dr. (Universitas Airlangga), titonslamet@gmail.com. 
bagi presiden untuk tetap dapat memerintah secara efektif. Atas dasar itu perlu dilakukan perubahan terhadap Pasal 6A ayat (2) UUD 1945 supaya penerapan asas presidensialisme dapat lebih konsisten. Partai politik seyogianya tidak lagi diberikan kekuasaan yang monopolistik sebagai pengusung pasangan calon presiden dan wakil presiden, termasuk dengan mengakomodasi kemungkinan pasangan calon presiden dan wakil presiden di luar jalur partai politik. Dengan ketentuan konstitusional yang demikian maka eksistensi ambang batas pencalonan presiden akan gugur dengan sendirinya.

Kata kunci: ambang batas pencalonan presiden, konstitusionalitas, presidensialisme.

\section{A. Introduction}

This article aims to discuss legal issues on the constitutionality of the presidential candidacy threshold (PT) related to the principles of the 1945 Constitution of the Republic of Indonesia covering the system of government. To be more specific, the system is the presidential system or presidentialism. ${ }^{1}$ The PT in this article refers to the PT according to Article 222 of the Law number 7 of 2017 on General Election (GE). The PT is a requirement for political parties or coalitions of political parties to be able to propose presidential/vice presidential candidates. The Article regulates that political parties or coalitions of political parties should obtain seats at least $20 \%$ (twenty percent) of the number of seats in the House of Representatives (DPR Dewan Perwakilan Rakyat) or obtain 25\% (twenty five percent) of the valid votes nationally in the previous General Election. This provision limits the opportunity for political parties to propose the presidential and vice-presidential candidates.

The Constitutional Court declares the PT is constitutional, both for the presidential elections which are held after the legislative elections and for the simultaneous presidential and legislative elections. ${ }^{2}$ This article intends to sharpen the ongoing debate. Indeed, the Constitutional Court's decision is final. However, the opinion on the constitutionality issue of the PT is not yet completed. The Constitutional Court does not enter into the substantive issue that the PT is fully in accordance with the principle of presidentialism because it only answers the issue

1 Presidentialism or presidential system is a special concept (species) of the general concept (genus) of system of government. The term presidential system or presidentialism used interchangeably here is also a legal concept with qualifications as a principle with the meaning of "norms whose up-front quality is exactly to determine the realization of a legally relevant purpose." Humberto Ávila, Theory of Legal Principles, Dordrecht: Springer, 2007, p. 138. Principles have a relationship with rules, "rules are justified by principles." Cass R. Sunstein, "Problems with Rules", California Law Review, Vol. 83, Issue 4, 1995, p. 966. Therefore, presidentialism is a principle serves to justify rules, for example, president as the executive leader is directly elected by the people as stipulated in Article 6A paragraph (1) of the 1945 Constitution. The existence of this rule is justified by the principle of presidentialism, which implies the independence of the executive from the legislative. Further, see the explanation in infra part B. Henceforth, the two terms, presidentialism and presidential system are used interchangeably because the two terms have the same meaning. See John Gerring, Strom C. Thacker and Carola Moreno, "Are Parliamentary Systems Better?", Comparative Political Studies, Vol. 42, Issue 3, 2009, pp. 327-359. The terms presidential system and presidentialism, as well as parliamentary system and parliamentarism, are used interchangeably.

2 The Constitutional Court Decision Number 51-52-59/PUU-VI/2008, Number 53/PUU-XV/2017, and Number 49/ PUU-XVI/2018. 
as an open legislative policy of the legislators. On the other hand, the Constitutional Court's opinion is produced with dissenting opinion. Parts of the Court actually examine the issue more substantively and provide a more convincing argument, which is based on the correct application of presidentialism principles. ${ }^{3}$

This study is of the position that the PT is contrary to the principle of presidentialism. The standpoint is both in the presidential election that is separated from and simultaneous with legislative elections. By the position, this article aims to criticize specifically the Constitutional Court's opinion on the constitutionality of the PT. Both of them are not built based on a proper consideration of the principle of presidentialism. The correct implementation of presidentialism should review the PT as in Article 222 of the Law number 7 of 2017, including the monopoly of political parties or coalitions of political parties in the nomination of presidential and vice-presidential candidate. Based on a proper understanding of the principle of presidentialism, the mechanism to elect president and vice president in general should be coherent with the principle of presidentialism.

The implication is the need to open space for presidential and vice-presidential candidates who are not nominated by political parties. It can be achieved by changing the provisions the president and vice president nomination in the 1945 Constitution. The current PT makes the commitment to the principle of presidentialism no longer pure. However, the idea is not totally incorrect because it is a logical consequence of the 1945 Constitution, which gives monopoly to political parties in the presidential and vice-presidential nomination and the law further regulates it. The PT becomes illogical because of the simultaneous presidential and legislative elections is an implication of the Constitutional Court Decision Number 14/PUU-XI/2013. Therefore, a more substantial target to be the recommendation of this article is the amendment to Article 6A paragraph (2) of the 1945 Constitution.

\section{B. President and Presidentialism}

The 1945 Constitution operates the principle of presidentialism. It is not because there is a political office literally called the president. The Constitution applies the principle because the Constitution adheres to the separation of powers to fill executive positions; and the most significant office is the president. In the Theory of the Constitution, it is covered by the government system. In this case, the system covers the relationship between the legislative and the executive. Cheibub and Limongi states as follows:

"the legal (constitutional and statutory) provisions that regulate the formation of the government, the rules for electing the legislative

3 The Constitutional Court Decision Number 53/PUU-XV/2017, pp. 137-146. 
assembly, the way the formation of each of these branches affects the performance of the others, the rules for producing legislation, and the behavior (strategic or otherwise) of the actors that make up the 'executive' (the head of government and the ministers) and the 'legislative' (individual legislators and political parties)."4

Cheibub emphasizes the aspect of the legislative body or parliament's ability to replace its government in the middle of office. According to Cheibub, "the main issue is whether the government can be removed by the assembly in the course of its constitutional term in office." ${ }^{5}$ In line with Cheibub, Skach argues that a government system is a concept of "constitutional models set out rules for the formation and termination of governments." 6

Literature notes that there are two most-popular systems of government: presidentialism and parliamentarism. In addition to the two poles-apart models, there is a combination of the two systems called semi-presidentialism. ${ }^{7}$ To get an easier understanding regarding the various concepts of government systems, the most adequate way is to explain the two concepts together and then present the contrast. By observing the differences, the essences of both presidentialism and parliamentarism can be better understood.

Lijphart takes such approach by pointing to three differences of presidentialism and parliamentarism. It aims to obtain a general understanding, at an abstractive degree, about the characteristics of each at the conceptual level. It is not at the level of positive law of a particular state. The first covers government and accountability of executive leader. In parliamentarism, executive leader governs based on the trust of parliament and is responsible to parliament simultaneously. In presidentialism, executive leader, called president, is independent from parliament. President is elected for a predetermined (fixed) term of office and cannot be removed by parliament due to the lack of political support. ${ }^{8}$ The second regards mechanism of election. In presidentialism, people directly elect executive leader. In parliamentarism, executive leader is elected by parliament. The basic principle is that the elected executive leader is directly proportional to the control of majority power in parliament because only majority power in parliament has the right to govern (act as government). In principle, the control of majority power in parliament is a guarantee for the continuity of parliamentarian government. This

Jose Antonio Cheibub and Fernando Limongi, "Legislative - Executive Relations" in Comparative Constitutional Law: Research Handbooks in Comparative Law, compiled by Tom Ginsburg dan Rosalind Dixon (eds.), Cheltenham-UK \& Northampton-USA: Edward Elgar Publishing, 2011, p. 211.

5 Jose Antonio Cheibub, Presidentialism, Parliamentarianism and Democracy, Cambridge: Cambridge University Press, 2007, p. 34.

6 Cindy Skach, "The 'Newest' of Separation of Powers: Semipresidentialism", International Journal of Constitutional Law, Vol. 5, Issue 1, 2007, p. 95.

7 Arend Lijphart, Patterns of Democracy: Government Forms and Performance in Thirty-Six Countries, New Haven-Connecticut: Yale University Press, 2012, pp. 105-129.

$8 \quad$ Ibid., p. 106. 
condition is clearly different with presidential system that defined executive leader to be in coalition with the people, not based on a majority in parliament. ${ }^{9}$ The third views position of the head of executive side. Presidentialism is stronger than parliamentarism because the executive leader practices single leadership. On the other hand, parliamentarism government is collegial in nature so that executive leader cannot make decision single-handedly. Decisions must be with the joint consent of the cabinet (ministers). It is clear that, legally speaking, the decisionmaking mechanism of presidential system is designed to be more efficient than parliamentary system. ${ }^{10}$

On the other hand, Linz believes that democracy is more inclined towards parliamentarism than presidentialism. ${ }^{11}$ Linz's view is based on his observations on presidentialism. According to Linz, presidentialism has as a zero-sum game tendency in the executive and legislative relationship. The implication is that regime is easy to be trapped into undemocratic and undesirable condition. ${ }^{12}$ Linz states that "the vast majority of the stable democracies in the world today are parliamentary regimes, where executive power is generated by legislative majorities and depends on such majorities for survival. By contrast, the only presidential democracy with a long history of constitutional continuity is the United States." ${ }^{13}$ Linz further explains the difference between presidentialism and parliamentarism as follows:

"In presidential systems an executive with considerable constitutional powers - generally including full control of the composition of the cabinet and administration - is directly elected by the people for a fixed term and is independent of parliamentary votes of confidence. $\mathrm{He}$ is not only the holder of executive power but also the symbolic head of State and can be removed between elections only by the drastic step of impeachment."14

Linz's opinion is in line with Lijphart's. Linz mentions that "a parliamentary regime in the strict sense is one in which the only democratically legitimate institution is parliament; in such a regime, the government's authority is completely dependent upon parliamentary confidence." 15 Substantively, the essential differences between the two concepts is "while parliamentarism imparts flexibility to the political

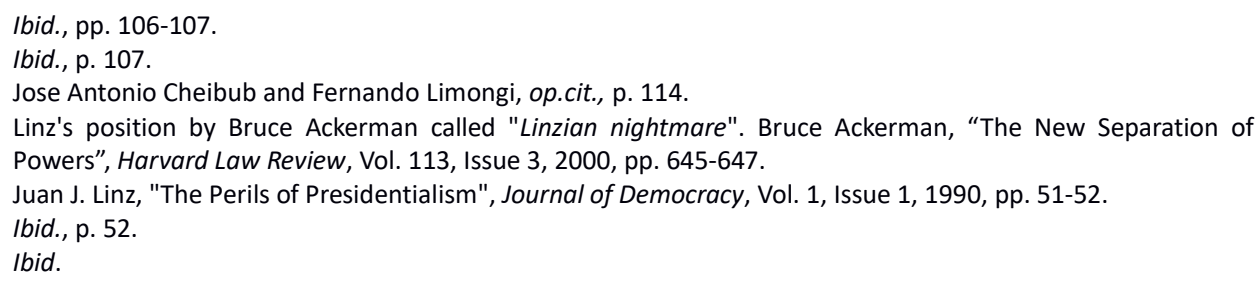


process, presidentialism makes it rather rigid". ${ }^{16}$ Based on his observations, presidentialism can easily turn into an authoritarian regime, especially because of the rivalry between executive and legislative, each of which stands on an equally solid basis of legitimacy based on the separation of the legislature -the executive with a strong democratic mandate (equally elected by the people). This explains the reason why Linz prefers parliamentarism to presidentialism in terms of the ability to sustain democracy.

The problem that can arise in the above scenario is parliament seats does not support government, the majority is in opposition.

"Under such circumstances, who has the stronger claim to speak on behalf of the people: the president or the legislative majority that opposes his policies? Since both derive their power from the votes of the people in a free competition among well-defined alternatives, a conflict is always possible and at times may erupt dramatically. There is no democratic principle on the basis of which it can be resolved, and the mechanisms the constitution might provide are likely to prove too complicated and aridly legalistic to be of much force in the eyes of the electorate." 17

A criticism to presidentialism is that its capacity to consolidate democracy is rather low due to the winner-take-all tendency of the system. It triggers the practice of zero-sum political rivalry in the relationship between executive and legislative. This situation can lead to a "strong contest". Linz calls it dual legitimacy. ${ }^{18}$ Responding Linz's criticism, Mainwaring and Shugart view that it is not the monopoly of presidentialism. ${ }^{19}$

In their criticism of Linz, Mainwaring and Shugart also discuss the concept of presidentialism as follows.

"By presidentialism we mean a regime in which, first, the president is always the chief executive and is elected by popular vote or, as in the US, by an electoral college with essentially no autonomy with respect to popular preferences and, second, the terms of office for the president and the assembly are fixed. Under pure presidentialism the president has the right to retain ministers of his or her choosing regardless of the composition of the congress." 20 
Presidentialism, according to Mainwaring and Shugart, has no substantial differences from the opinions discussed above. It can be concluded that presidentialism has converged as a general concept of the opinions of experts, which are compatible with each other.

However, the discussion is not sufficient. At this point, the discussion is quite interesting because Mainwaring and Shugart and Linz take different positions in assessing the presidentialism. Mainwaring and Shugart's significant response to Linz's criticism of presidentialism's weaknesses in terms of its ability to consolidate democracy is a positive aspect of presidentialism, which is precisely the object of Linz's criticism. Contrary to Linz, Mainwaring and Shugart highlight several advantages of presidentialism. The first is greater choice on the part of voters. Voters have the opportunity to elect president candidate and legislative members from different parties. The second is the tendency of elected officials to be accountable to voters because the people directly elect president. The third is the freedom of legislators to exercise legislative power. ${ }^{21}$ This opinion is in line with Calabresi who says that the positive values of presidentialism are "more democratic, more stable, less ideological, more protective of judicial review, and more libertarian than will be parliamentary regimes, all else being equal."22

The essence of the notions of parliamentarism and presidentialism can be found in the opinion of Skach. ${ }^{23}$ Skach states,

"Parliamentarism is characterized by a fusion of powers and a mutual dependence between the executive and the legislative powers. This is due to the fact that the chief executive (usually a prime minister or chancellor) emanates from the legislature after elections and needs the confidence of the legislature in order for his government to survive the duration of the legislature's term."24

On presidentialism, Skach argues,

"it is a system characterized by the separation of powers and a mutual independence of the executive and legislative powers. This is because the chief executive (a popularly elected president) and the legislature are elected independently of each other, for fixed terms of office, and both can survive for their respective terms without the other's approval." 25

Steven G. Calabresi, "The Virtues of Presidential Government: Why Professor Ackerman is Wrong to Prefer the German to the US Constitution", Constitutional Commentary, Vol. 18, Issue 1, 2001, p. 56.

Compare with Jose Antonio Cheibub, op.cit., p. 1.

Cindy Skach, loc.cit.

lbid., p. 96. 
This opinion describes a juridical rather than political meaning.

Finally, the main asset to understand the essence of presidential power according to the principles of presidentialism is the inherent conception of presidentialism. Rose-Ackerman (et. al) explain the essence of presidentialism. They claim, "The essence of presidentialism is the separation of powers, but the overlapping notion of checks and balances is equally important." 26 In presidentialism, the most important thing is the separation of executive and legislative powers. This is a form of prescription for the conception of presidentialism where executive power does not depend on the trust of the parliament. Checks and balances are just decorations in terms of the design of presidentialism as desired; it is Presidentialism where the president holds absolute power or presidentialism in which the president holds limited power. Therefore, Rose-Ackerman et al. define presidentialism in the context of constitutionalism. In that case, checks and balances are treated as important as the separation of powers so that the presidential power generated by the presidential system has limited power.

Rose-Ackerman (et. al) agree with Calabresi as follows:

"I shall conflate the term 'presidentialism' with the term 'separation of powers' because all presidential regimes, as the term is generally understood, have a separately elected executive and legislature, hence the phrase the separation of powers. I shall distinguish presidential regimes here from parliamentary regime with operative definition being that in a parliamentary regime the head of government (who I shall generally refer to as the Prime Minister) is responsible to the legislature in the sense that he is dependent on the legislature's confidence and can be dismissed from office by a legislative vote of no confidence. In contrast, in a presidential system the president and legislature are elected separately, and the President holds his office for a fixed term of years." 27

The definition above is the starting point for the notion of presidentialism in the mechanism to form government, especially to fill executive positions (president and vice president). The concept of separation, based on presidentialism, essentially lies in a separately elected executive offices and legislative seats.

President, according to the principles of presidentialism, occupies a central position. It is vice versa to the parliamentary system placing parliament in a central position because the holder of executive power comes from the majority of the parliament. As an implication, parliamentary system applies parliamentary

26 Susan Rose-Ackerman, Diane A. Desierto and Natalia Volosin, "Hyper-Presidentialism: Separation of Powers without Checks and Balances in Argentina and the Philippines", Berkeley Journal of International Law, Vol. 29, Issue 1, 2011, p. 247.

27 Steven G. Calabresi, op.cit., pp. 54-55. 
supremacy with the assumption that parliament is the holder of the highest power as the embodiment of the will of the people. ${ }^{28}$ In accordance with the principles of presidentialism, the position and relationship of legislative executive is built based on equality: each position equals to the other; and both positions receive direct mandate from the people (dual legitimacy). The difference is that the executive, namely the president, is one person. On the other hand, parliament consists of many people. In such arrangement, efficiency and effectiveness of president is clearly far superior to that of parliament, which shares a very strong mandate as representatives of the people, directly elected by the people themselves.

\section{Constitutionality of Presidential Candidacy Threshold: Pros and Cons}

The Constitutional Court has tested the constitutionality of the PT before it decides the PT constitutional. The decision has implications for the simultaneous implementation of the legislative and presidential elections. ${ }^{29}$ However, the moment of the examination was not quite right. Therefore, the Constitutional Court's statement that the PT is an open legislative policy is rational. ${ }^{30}$ The Constitutional Court's decision brings implications for the simultaneous legislative and presidential elections. One of them is that the constitutionality of the PT is requestioned. The focus is the rationale of the 2019 simultaneous legislative and presidential elections. ${ }^{31}$ The controversy over the PT's constitutionality is explained in reference to The Constitutional Court Decision Number 53/PUU-XV/2017 and Number 49/PUU-XVI/2018.

The valid justification for the enforceability of the provisions of PT, in the initial analysis before being criticized, must be seen from the legislative policies. The President, in a statement delivered at the Court's trial, explains the legislative policy of PT is a reflection of the strong initial support from the DPR. The DPR is a symbol of the people's representation in the nomination of presidential and vicepresidential candidates by political parties or coalitions of political parties. Thus, the requirements of the nomination of the president and vice president are regulated in Article 222 of the Law number 7 of 2017. Regarding the support of political parties, the requirements are in line with the mandate of the constitution, which describes the sovereignty of the people. In addition, it is the realization of sustainable development through a more effective and more stable presidential system of government. These provisions are intended as prerequisites, or preliminary

\footnotetext{
28 Suwoto Mulyosudarmo, Peralihan Kekuasaan: Kajian Teoretis dan Yuridis terhadap Pidato Nawaksara, Jakarta: PT Gramedia Pustaka Utama, 1997, p. 22.

29 The Constitutional Court Decision Number 14/PUU-XI/2013.

30 The Constitutional Court Decision Number 51-52-59/PUU-VI/2008, pp. 184-185.

31 The Constitutional Court Decision Number 53/PUU-XV/2017 and Number 49/PUU-XVI/2018.
} 
selection, that show the level of trust of the candidates of president and vice president as reflected in the support of the voters. ${ }^{32}$

This reason is illogical because it uses the results of the previous election as a basis for the DPR's support for the presidential and vice-presidential candidate pairs. In fact, the support base is not necessarily the same as the legislative election that is still going to take place -simultaneously with the presidential election. The DPR, on the other hand, did not convey a substantive opinion on the PT from the legislative policy perspective. The DPR only refers to the opinion of the Constitutional Court in the previous decision that qualifies the PT provisions as still included in an open legislative policy. ${ }^{33}$ Then, despite the fact that the implementation mechanism changes (from not simultaneously to simultaneously), the Constitutional Court's opinion is still valid mutatis mutandis.

The Constitutional Court's opinion, with the complementary dissenting opinion, is the focus of our next discussion. The discussion on the relationship between the PT and presidentialism as a principle of the 1945 Constitution from the beginning has become a concern of the Constitutional Court. For this reason, the Constitutional Court, specifically in the starting point of its opinion, reminds the political agreement in the People's Consultative Assembly (MPR -Majelis Permusyawaratan Rakyat). One of them is the strengthening of presidentialism. ${ }^{34}$ However, the Constitutional Court also realizes that the implementation of presidentialism principles also requires an adequate "political environment". When the simplification of political parties cannot be carried out effectively, the consistent implementation of presidentialism will remain problematic. ${ }^{35}$ This stance shows that the Constitutional Court is trying to be realistic since the Constitutional Court's concern does not cover only the legal aspect. It also includes the operational continuity of the presidentialism principles to be dependent on real political factors, as well as a very important variable in the consistent implementation of the principle of presidentialism in Indonesia.

Fears of not getting the support of a majority of political parties in the DPR may force the president to compromise by forming a multiparty coalition. This is a consequence of a multiparty system. Normally, it is very difficult for the president to get the support of a majority of political parties in the DPR without making such political compromises. The Constitutional Court is well aware of this political reality. ${ }^{36}$ Therefore, to tolerate this political reality, the Constitutional Court also gave a compromise and political opinion. According to the Constitutional Court, Article 222 of the General Election Law is based on this spirit. With the enactment of the minimum number of votes acquired by political parties or coalitions of

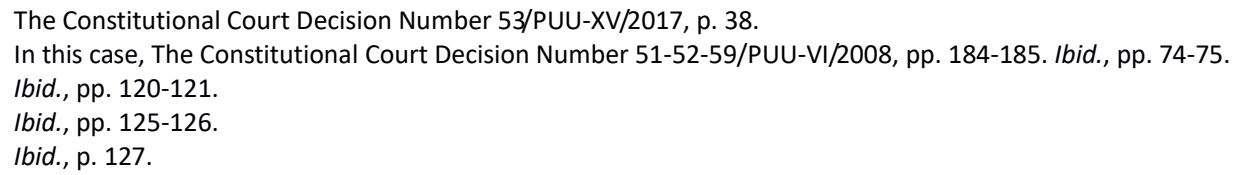


political parties from the start to be able to nominate pairs of candidates for President and Vice President, it means that from the start two conditions for the presence of strengthening the Presidential system are expected to be fulfilled. They are, first, efforts to fulfill the adequacy of political party vote support or coalition of political parties supporting the presidential and vice-presidential candidate pairs in the DPR; and, second, simplifying the number of political parties. ${ }^{37}$ In addition to the opinion, the Constitutional Court also states as follows.

"Dalam konteks yang pertama, dengan memberlakukan syarat jumlah minimum perolehan suara bagi partai politik atau gabungan partai politik untuk dapat mengusulkan pasangan calon Presiden dan Wakil Presiden maka sejak awal pasangan calon Presiden dan Wakil Presiden yang bersangkutan telah memiliki cukup gambaran atau estimasi bukan saja perihal suara yang akan mendukungnya di DPR jika terpilih tetapi juga tentang figur-figur yang akan mengisi personalia kabinetnya, yang tentunya sudah dapat dibicarakan sejak sebelum pelaksanaan Pemilu melalui pembicaraan intensif dengan partai-partai pengusungnya, misalnya melalui semacam kontrak politik di antara mereka. Benar bahwa belum tentu partai-partai pendukung pasangan calon Presiden dan Wakil Presiden akan menguasai mayoritas kursi di DPR sehingga pada akhirnya tetap harus dilakukan kompromi-kompromi politik dengan partai-partai peraih kursi di DPR, namun dengan cara demikian setidak-tidaknya kompromi-kompromi politik yang dilakukan itu tidak sampai mengorbankan hal-hal fundamental dalam program-program pasangan calon Presiden dan Wakil Presiden yang bersangkutan yang ditawarkan kepada rakyat pemilih dalam kampanyenya. Dengan demikian, fenomena lahirnya "sistem Presidensial rasa Parlementer" dalam penyelenggaraan pemerintahan dapat direduksi."

[In the first context, by imposing a minimum number of votes for political parties or coalitions of political parties to be able to nominate pairs of candidates for President and Vice President, from the start the pairs of candidates for President and Vice President concerned have sufficient description or estimation. This not only includes the matter of votes that will support them in the DPR if they were elected, but it also includes the figures who will fill his cabinet personnel. Indeed, this can be discussed since before the implementation of the General Election through intensive discussions

$37 \quad$ lbid., pp. 127-128. 
with the supporting parties, for example through a kind of political contract between them. It is true that it is not certain that the parties supporting the presidential and vice-presidential candidate pairs will control the majority of seats in the DPR, so in the end political compromises must be made with the parties that win seats in the DPR. However, in this way, at least the political compromises made do not compromise the fundamentals in the programs of the pairs of candidates for President and Vice President that are offered to voters in their campaign. Thus, the phenomenon of the birth of a "parliamentary-in-nature presidential system" in the government administration can be reduced.] $]^{38}$

Then, explaining the relationship between the provisions of the PT and the simplification of political parties, the Constitutional Court states,

"dengan sejak awal partai-partai politik bergabung dalam mengusulkan pasangan calon Presiden dan Wakil Presiden berarti sesungguhnya sejak awal pula telah terjadi pembicaraan ke arah penyamaan visi dan misi partai-partai politik bersangkutan yang bertolak dari platform masing-masing yang kemudian secara simultan akan dirumuskan baik ke dalam program-program kampanye pasangan calon Presiden dan Wakil Presiden yang diusung maupun dalam program-program kampanye partai-partai pengusung pasangan calon Presiden dan Wakil Presiden tersebut yang akan ditawarkan kepada rakyat pemilih. Dengan cara demikian, pada saat pelaksanaan Pemilu, rakyat pemilih akan memiliki referensi sekaligus preferensi yang sama ketika memilih pasangan calon Presiden dan Wakil Presiden dan ketika memilih calon anggota DPR dari partaipartai pengusung pasangan calon Presiden dan Wakil Presiden itu sebab Pemilu akan dilaksanakan secara serentak. Artinya, rakyat pemilih telah sejak awal memiliki gambaran bahwa jika memilih pasangan calon Presiden dan Wakil Presiden tertentu karena setuju dengan program-program yang ditawarkannya maka secara rasional juga harus memilih anggota DPR dari partai politik yang akan mendukung tercapainya program-program tersebut yang tidak lain adalah partai-partai politik pengusung pasangan calon Presiden dan Wakil Presiden tersebut. Pada perkembangan selanjutnya, apabila partai-partai politik yang bergabung dalam mengusung pasangan calon Presiden dan Wakil Presiden tersebut berhasil menjadikan pasangan calon Presiden dan Wakil Presiden yang diusungnya itu terpilih menjadi Presiden dan Wakil Presiden maka dengan sendirinya

$38 \quad$ Ibid., p. 128. 
partai-partai politik tersebut menjadi partai-partai yang memerintah (the ruling parties) yang secara logika politik telah berada dalam satu kesatuan pandangan dalam tujuan-tujuan politik yang hendak dicapai atau diwujudkan. Pada titik itu sesungguhnya secara etika dan praktik politik partai-partai politik tersebut telah bermetamorfosis menjadi satu partai politik besar sehingga dalam realitas politik telah terwujud penyederhanaan jumlah partai politik kendatipun secara formal mereka tetap memiliki identitas tertentu sebagai pembeda namun hal itu tidak lagi secara mendasar mempengaruhi kerjasama mereka dalam pencapaian tujuan-tujuan mereka yang tercermin dalam program-program dan kinerja pasangan Presiden dan Wakil Presiden yang mereka usung bersama." [since political parties joined forces to nominate candidates for President and Vice President, there have been discussions towards a common vision and mission of the political parties concerned, starting from their respective platforms. The vision and mission will then be simultaneously formulated both in the campaign programs of the pairs of candidates for President and Vice President that are carried, as well as in campaign programs for the parties carrying the pairs of the candidates of President and Vice President. These programs will be offered to the voters. In this way, at the time of the Election, voters will have the same reference when choosing pairs of candidates for President and Vice President, as well as when choosing candidates for DPR members from the parties carrying the pairs of candidates for President and Vice President, because the Election will be held in a manner simultaneously. This means that voters, from the beginning, have an idea that if they choose a certain pair of candidates of President and Vice President because they agree with the programs they offer, then rationally the people must also elect members of the DPR from political parties who will support the achievement of these programs. These parties are none other than the political parties that carry the presidential and vice-presidential candidates. In further developments, if the coalition of political parties that nominated the candidate pair for President and Vice President is successful - the pair of candidates for President and Vice President that they carry are elected - so automatically these political parties become the ruling parties. In political logic, they have been in a united view of the political goals to be achieved or realized. At that point, ethically and practically, these political parties have 
metamorphosed into one big political party. In the political reality, a simplification of the number of political parties has been materialized. Although formally they still have a certain identity as a differentiator, it no longer fundamentally affects their cooperation in achieving their goals, which are reflected in the programs and performance of the pair of President and Vice President they nominated together]. ${ }^{39}$

Based on the political pre-understanding above, the Constitutional Court provides an interpretation of Article 6A paragraph (2) of the 1945 Constitution as follows:

"Sesungguhnya dalam kedua konteks itulah frasa "sebelum pelaksanaan pemilihan umum" dalam Pasal 6A ayat (2) UUD 1945 didesain dan karenanya dalam kedua konteks itu pula seharusnya diimplementasikan. Dengan kata lain, Pasal 6A ayat (2) UUD 1945 yang selengkapnya berbunyi, "Pasangan calon Presiden dan Wakil Presiden diusulkan oleh partai politik atau gabungan partai politik peserta pemilihan umum sebelum pelaksanaan pemilihan umum" adalah norma Konstitusi yang memuat desain konstitusional penguatan sistem Presidensial dengan semangat, di satu pihak, mendorong tercapainya kepararelan perolehan suara pasangan calon Presiden dan Wakil Presiden dengan peroleh suara partai-partai politik pendukung pasangan calon Presiden dan Wakil Presiden tersebut di DPR serta, di pihak lain, mendorong terwujudnya penyederhanaan partai di mana ke dua hal itu merupakan penopang utama bekerjanya sistem Presidensial dalam praktik penyelenggaraan pemerintahan negara. Bahwa dalam praktik hingga saat ini keadaan demikian belum terwujud, hal itu bukanlah berarti kelirunya desain konstitusional di atas melainkan terutama karena belum berjalannya fungsi-fungsi partai politik sebagai instrumen pendidikan dan komunikasi politik."

[In fact, it is in both contexts that the phrase "before the implementation of general elections" in Article 6A paragraph (2) of the 1945 Constitution was designed. Therefore, the implementation should be carried out in both contexts as well. In other words, Article 6A paragraph (2) of the 1945 Constitution, which reads in full, "The pair of candidates for President and Vice President proposed by political parties or coalitions of political parties participating in the general election before the implementation of general elections" is a constitutional norm containing a constitutional design to strengthen the Presidential system. The spirit contained is, on the one hand, to 
promote the achievement of a parallel vote acquisition for the presidential and vice-presidential candidate pairs by obtaining the votes of political parties that support the presidential and vicepresidential candidates in the DPR. On the other hand, the spirit is to promote number of parties reduced. These two things are the main pillars of the functioning of the presidential system in the practice of state governance. In practice to date, this situation has not yet materialized. This does not mean that the constitutional design is wrong. Rather, it is mainly due to the ineffectiveness of the functions of political parties as instruments of political education and communication. $]^{40}$

Did they who formed the amendment to the 1945 Constitution really think that as the result of Article 6A paragraph (2) of the 1945 Constitution? This question places the validity of the constitutional interpretation carried out by the Constitutional Court as the object. If the amendments to the 1945 Constitution were performed based on the same thoughts, then this thought is not a rule because, in presidentialism principles, such a rule is clearly wrong, and the Constitutional Court must know that in order to provide correction.

The Constitutional Court still maintains its stance on the constitutionality of the PT by referring to the opinion aims to respond the issue of the PT's constitutionality where the implementation of the legislative and presidential elections is still separates (in this case the Constitutional Court Decision number 51-52-59/PUU$\mathrm{VI} / 2008)$. The reasons for maintaining this stance are as follows.

"argumentasi teoretik konstitusionalitas persyaratan mengenai ambang batas minimum perolehan suara partai politik (atau gabungan partai politik) untuk dapat mengusulkan calon Presiden dan Wakil Presiden bukanlah diturunkan dari logika disatukan atau dipisahkannya Pemilu untuk memilih Presiden/Wakil Presiden dengan pemilu untuk memilih anggota DPR, DPD dan DPRD melainkan dari argumentasi teoretik untuk memperkuat sistem Presidensial dalam pengertian mewujudkan sistem dan praktik pemerintahan yang makin mendekati ciri/syarat ideal sistem pemerintahan Presidensial sehingga tercegahnya praktik yang justru menunjukkan ciri-ciri sistem Parlementer."

[theoretical arguments of constitutionality regarding the minimum threshold requirement acquired by political parties (or coalitions of

$40 \quad$ Ibid., pp. 129-130. 
political parties) to be able to nominate candidates of President and Vice President are not generated from the logic of unifying or separating the Presidential Election from the legislative elections. It is rather from theoretical arguments to strengthen the Presidential system in the sense of realizing government systems and practices that are closer to the ideal characteristics/requirements of the Presidential government system. In this way, practices that show the characteristics of a Parliamentary system can be prevented]. ${ }^{41}$

In addition to the above arguments, the Constitutional Court adds the sociopolitical argumentation of the PT's constitutionality as to strengthen the Presidential institution that reflects the socio-political legitimacy of the diverse representations of Indonesian society. ${ }^{42}$

The main point of a criticism against the Constitutional Court's opinion, in relation to the PT's constitutionality, is that the opinion of the Constitutional Court is very conservative in considering the role of political parties while forgetting the essence of presidentialism. Saldi Isra and Suhartoyo's dissenting opinion is more precise and consistent from the perspective of the presidentialism principles, namely the independence of the executive from the legislative powers.

"Dalam sistem presidensial, melalui pemilu langsung, mandat rakyat diberikan secara terpisah masing-masing kepada pemegang kekuasaan legislatif dan kepada pemegang kekuasaan eksekutif (presiden). Karena sama-sama berasal dari pemilihan langsung, mandat yang diberikan kepada pemegang kekuasaan legislatif belum tentu sama, bahkan sejumlah fakta empirik membuktikan acapkali berbeda, dengan mandat yang diberikan kepada pemegang kekuasaan eksekutif. Menggunakan hasil pemilu legislatif guna mengisi posisi pemegang kekuasaan eksekutif merupakan logika dalam pengisian posisi pemegang kekuasaan eksekutif tertinggi dalam sistem parlementer. Artinya, dengan logika sistem pemerintahan, mempertahankan ambang batas (presidential threshold) dalam proses pengisian jabatan eksekutif tertinggi jelas memaksakan sebagian logika pengisian jabatan eksekutif dalam sistem parlementer ke dalam sistem presidensial."

[In a presidential system, a direct election provides the mandate of the people separately to the legislative power and to the executive power (president). Because they both come from direct elections, the mandate given to the legislative power holders is not necessarily the same, even a number of empirical facts prove that it is often different 
from the mandate given to the executive power. Using the results of legislative elections to fill positions of executive power holders is logical to fill the position of the highest executive power in a parliamentary system. This means, with the logic of the government system, maintaining the presidential threshold in the process of filling the highest executive position clearly forces part of the logic of filling executive positions in the parliamentary system into the presidential system]. ${ }^{43}$

The point of the dissenting opinion above is a very strong rebuttal of the opinion of the majority of the Constitutional Court judges. The opinion above emphasizes the juridical aspect, in this case the principle of presidentialism, rather than political aspect, in this case the president's ability to govern if he gets the support of minority factions in parliament. Furthermore, the dissenting opinions also respond to political arguments in the final Constitutional Court's opinion.

"Bagaimana mungkin argumentasi untuk membangun stabilitas tersebut dapat dibenarkan jika peluang partai politik peraih kursi atau suara sah tidak bisa dijamin untuk dapat bertahan di DPR? Selain itu, bentangan empirik yang terjadi sepanjang praktik sistem pemerintahan presidensial multipartai sejak pemilihan presiden langsung 2004, dukungan partai politik (dalam bangunan koalisi) kepada presiden lebih merupakan atau lebih banyak dukungan semu. Biasanya, semakin dekat penyelenggaraan pemilu, partai politik yang tergabung dalam koalisi kian merasa tidak terikat dengan koalisi yang dibangun di awal masa pemerintahan."

[How can the arguments to build stability be justified if the chances of political parties winning seats or valid votes to survive in the DPR cannot be guaranteed? In addition, the empirical facts have occurred throughout the practice of the multiparty presidential system of government since the 2004 direct presidential election. The support of political parties (in a coalition building) for president is more or less false support. Usually, the closer the election time, the more political parties that are members of the coalition feel that they are not tied to the coalition that was built at the beginning of the government]. ${ }^{44}$

This opinion is more factual than the opinion of the Constitutional Court. It means that there is a very serious problem in the judicial opinion of the Constitutional

43 The Constitutional Court Decision Number 53/PUU-XV/2017, p. 141.

44 Ibid., pp. 143-144. 
Court, which adheres to the school of Realism. This opinion is not factual, although for the opinion, the Constitutional Court had tried to be factual rather than juridical. $^{45}$

In re-examining the PT's constitutionality, the Constitutional Court continues to hold on to the stance. In the Decision Number 49/PUU-XVI/2018, the Constitutional Court re-applies the ratio decidendi from the Decision Number 53/PUU-XV/2017 to respond the constitutionality issue. ${ }^{46}$ That means that, in retesting the PT's constitutionality, the Constitutional Court still concludes that the PT is constitutional with the same opinion or legal considerations as described above.

\section{Juridical Solutions to Indonesian Presidential Problems}

This section responds to and criticizes the opinion of the Constitutional Court. Therefore, this discussion is either evaluative or normative. In principle, this discussion agrees with the dissenting opinion point of the Constitutional Court Decision Number 53/PUU-XV/2017. However, this discussion further elaborates these points as a total critical note towards the solution to strengthen the implementation of presidentialism principles offered by the Constitutional Court in supporting the PT's constitutionality.

The Constitutional Court has failed to make a firm constitutional ruling on the issue of the PT's constitutionality, in particular, and the issue of implementing the principles of presidentialism, in general. The main issue of the implementation of the principles of Indonesian presidentialism is the concern over the political reality that the parliament may not side with the governing president. In other words, the elected president only has minority political support in the parliament. This situation is always logical because, in presidentialism, the principle of separation of powers run with two different legislative and presidential elections. ${ }^{47}$ The results of the legislative elections are not always directly proportional to the results of the presidential election. For example, this also happens in the United States. President who rules with the support of minorities in parliament may be difficult to govern. Therefore, to strengthen the political position of the President, the Constitutional Court with its socio-political arguments supports the enforcement of the PT's provisions with the aim of strengthening the implementation of the principles of presidentialism. Such arguments are actually political arguments, not legal arguments. Legal arguments should be based on the principle of presidentialism. Therefore, if the focus of the Constitutional Court is "juridical", the Constitutional

45 Realism approach is an approach in adjudication in which the weight of legal considerations is more inclined to the factual considerations of the case rather than its own juridical considerations. Holmes states that such factual or non-juridical considerations are often "The felt necessities of the time, the prevalent moral and political theories, intuitions of public policy, avowed or unconscious, even the prejudices which judges share with their fellow-men." Oliver Wendell Holmes, The Common Law, Cambridge-Massachusetts: Harvard University Press, 2009, p. 3.

46 The Constitutional Court Decision Number 49/PUU-XVI/2018, p. 44.

47 See discussion B. 
Court should not have to worry about "political" matters, namely the difficulty of an elected president when ruling with only minority political support in parliament.

Contrary to the opinion of the Constitutional Court, this study provides a more precise argument in the implementation of the principle of presidentialism by only focusing on juridical factors. The proposed solution focuses on "disciplining" the opposition through the rules of opposition because the "practice" of the opposition so far has often been without rules, just trying to appear different from the rulers to get an electoral impact on the upcoming elections. The practices of that opposition should be based on political morality from a commitment to implement the principles of presidentialism consistently. Being opposition in a presidential system has limits. Opposition has a constitutional obligation to give the elected president the maximum opportunity to rule, complying political promises in the context of respecting the people's sovereignty -for example, the role of the DPR in approving the State Revenue and Expenditure Budget. Agreement here essentially means supervision. By having the authority to give approval, the DPR can, of course, disagrees the draft proposed by president. However, in relation to the principles, the DPR, especially the "opposition", should only disagree if the draft does not reflect the president's political promises to the people. Vice versa, if the draft reflects the president's political promises to the people, the reasons for disapproving will no longer exist because the principle is that the DPR, especially the "opposition", must give the president the widest possible opportunity to govern so that the government can succeed. At least the president does not fail.

Such a rule is actually a logical implication of the principle of presidentialism that the president cannot be overthrown by parliament because of his policies. Vice versa, the president cannot dissolve the parliament. The role of the opposition political force in the parliament is to supervise. On the other hand, in presidentialism, the issue of supervision needs to be clarified so that it does not become parliamentarism. In a very abstract formulation, this study is of the position to see the political morality of the commitment to implement the principles of presidentialism in a pure or consistent manner. Such moral rules can only be understood by understanding the philosophy of the principles of presidentialism in advance.

The philosophical foundation of the principle of presidentialism appears, in the initial analysis, in the justification that the president must be directly elected by the people and, in principle, hold office in a fixed term of office. Such design actually contains certain virtues that need to be understood as its philosophical basis. RoseAckerman (et. al) propose a very relevant idea to explain the philosophy of presidentialism. 
"The goal of the presidential election is to select a person who can operate as a strong manager independent of the legislature, and who can concentrate on administering the law fairly and competently. To assure this independence, the president is elected separately, governs for a fixed term, and cannot be removed by a legislative vote of no confidence. Each branch has a well-specified role. No branch can exceed its mandate, and the ideal is limited and effective government." 48

The direct support of the popular vote certainly has a specific intrinsic meaning compared to the indirect support, such as in parliamentarism. The position of president elected by the people is directly parallel to the position of the parliament whose members are also directly elected by the people with different electoral objectives. As mentioned earlier, institutionally, this model of executive-legislative relations starts from the understanding that executive is not dependent on legislative. The executive rules based on the direct mandate of the people, not the parliament. The core of opinion of Rose-Ackerman et al., which needs to be underlined here, is that presidential election is "to select a person who can operate as a strong manager independent of the legislature, and who can concentrate on administering the law fairly and competently".

The opinion of Rose-Ackerman (et. al) is that president is a political figure who is "expected" to be strong in the sense that president does not need to depend on parliamentary political support. Parliament has their own powers and, therefore, as the basis for their democratic legitimacy, they are also directly elected. The difference with president is the number of persons filling parliament, while president only provides single seat. This is the specialty of presidentialism because president is a political figure who is expected to be able to "concentrate on administering the law fairly and competently." In another sense, its singular composition is an institutional advantage compared to the legislative. Based on the mechanism of direct elections by the people,

"presidents, after all, run in national level - unlike legislators, who often have a more parochial base of representation. Presidents are thus in a position to claim that they are the rightful interpreters of the national interest, superseding legislators' partial and parochial perspectives." 49

Such election model clearly contains symbolic meaning, namely as "the rightful interpreters of the national interest" whose position overrides parliament because of its "partial and parochial perspective." President is a national leader because the

Susan Rose-Ackerman, Diane A. Desierto and Natalia Volosin, op.cit., pp.247-248.

Jose Antonio Cheibub, op.cit., pp. 8-9. 
constituents are at national level. Therefore, president has the right to claim to be the representative of all the people. Members of parliament are the opposite. They act as representatives of the people in their constituencies. Therefore, as a representation of the people, the label attached to them is "more parochial base of representation."

This definition is the principle in the definition of executive power by Thomas Jefferson, the President of the United States. Jefferson put forward his thoughts on the power of president against the background of the election mechanism as follows.

"The president unifies the will of the nation and embodies it. The source of the president's claim to embody the will of the nation is his mode of election; because the president is the single nationally elected officer, the president can claim, more than members of Congress, to represent the national will. Because the president must be able to execute that will, it must be surprisingly strong, or energetic." 50

Jefferson illustrates that president as executive leader who is elected by the people, not elected by the parliament, is a very democratic institution and, therefore, able to unite the will of the people. Therefore, it is in the hands of president that the will of the nation must be carried out, so that a president must have the capacity to do so.

In principle, the president-election mechanism in presidentialism provides a picture of a very democratic process because the people are given an opportunity to determine their executive leader. Therefore, in dealing with a parliament that has a democratic mandate, president also has a similar mandate. Calabresi describes the president-election model in the United States, which has a presidential system, and compares it to the model in Germany, which is a parliamentary system (the system is generally semi-presidential). Calabresi claims that the American system, in particular, is mutatis mutandis the presidential system in general. "More democratic and more sophisticated in its mechanism for sampling the Popular Will". ${ }^{1}$ The adequacy of the representation of the public votes in determining executive leader is a very fundamental issue of democracy. The opportunity for each citizen to vote president in a presidential system represents "more accurate samples the popular

\footnotetext{
50 Jeremy D. Bailey, Thomas Jefferson and Executive Power, Cambridge: Cambridge University Press, 2007, pp. 910.

51 Steven G. Calabresi, op.cit., p. 56.
} 
will", 52 especially when it is realized that the popular will is the basis of democratic governance.

Furthermore, the last philosophical perspective of presidentialism is the guarantee of governance stability. This is represented by the "fixed term" element in the executive (presidential) and legislative terms of office. Stability of governance is a very important issue that is highlighted by Calabresi. Calabresi states, "Just as it is vital for a democracy to take many accurate soundings of public opinion, so too is it vital that the winners be empowered to act once the elections have been held." ${ }^{\prime 3}$ As we have seen, protection for the executive, as well as the legislature, in the form of a fixed term of office cannot be compromised in presidentialism.

"Presidential government solves the problem of stability by guaranteeing that the executive and legislative officers will serve for a fixed term of years regardless of subsequent events and regardless of the extreme demands of a few of the government's supporters. Even when an election produces an indeterminate compromise outcome by, for example, producing divided party control of the presidency and the legislature, the compromise result is a stable one for a fixed term of years." 54

This condition is very favorable because government does not come and go. Thus, the sustainability of national policy, in a relatively short period of time following the term of office of the president, including the limitation of the term of office, can always be maintained.

Based on the earlier explanation, the reflective question for Indonesian politics in the future is whether the commitment to the implementation of the pure principle of presidentialism only to be focused on the presidential election by being directly elected by the people and the role of the dominant political party in it. Alternatively, does it, for this commitment, also include the philosophy of the principle of presidentialism as explained earlier? This study is of the last position.

In other words, if it is related to the opinion of the Constitutional Court regarding the constitutionality of the $\mathrm{PT}$, it can be concluded that the Constitutional Court has actually failed in capturing the spirit of presidentialism philosophy. Its opinion is not straightforward. Joining presidentialism and parliamentarism, from the Constitutional Theory, is actually a union of two things that cannot be put together except because of compulsion. The Constitutional Court has responded to the issue of president's power to govern incorrectly. Faith on the philosophy of presidentialism should eliminate such worry. Moreover, Indonesian politics is very fluid. The factual argument of the Constitutional Court is actually "fictional". It does not correspond to facts. One of the evidences is the 2019 presidential election in

Ibid., p. 59.

Ibid.

Ibid., p. 61. 
which President Joko Widodo managed to attract his political rival, Prabowo Subianto, to join the government. This is certainly unfortunate because the political considerations of the Constitutional Court have missed an important moment to strengthen presidentialism in Indonesia.

The Constitutional Court seems too conservative in responding to the role of political parties. This ignores the essential of the principles of presidentialism. The direct presidential election by the people principally places the president in a coalition with the people rather than with political parties. It is the true sovereignty of the people. To all intents and purposes, political parties (especially the opposition) must respect it. The principle has been confirmed factually, although it cannot be generalized. The 2019 presidential election shows that the votes acquired by the elected president are not directly proportional to the votes acquired by the winning political parties. This means that political parties are not fully able to convince their constituents to elect their presidential and vice-presidential candidate pairs. Therefore, the consistent application of the principle of presidentialism, namely the independence of the executive from the legislative, is not relevant to the enforcement of the PT. That means, supposedly, all political parties participating in the legislative elections have the right (so that they are free) to carry their own presidential/vice presidential candidate pairs. In another sense, if the basis is presidentialism, then the regulation regarding the requirements for the support of a presidential/vice presidential candidate by a political party is to pay more attention to the figure of candidate to be promoted, not the political party.

Consistent application of the principle of presidentialism, namely the independence of the executive from the legislature is not relevant to the enforcement of the provisions of PT. That means, supposedly, all political parties participating in the legislative elections have the right (so that they are free) to carry their own presidential/vice presidential candidate pairs. In another sense, if the basis is presidentialism, then the regulation regarding the requirements for the support of a presidential/vice presidential candidate by a political party is to pay more attention to the figure or figure of the candidate to be promoted, not the political party that supports it. Consistent application of the principle of presidentialism, namely the independence of the executive from the legislature is not relevant to the enforcement of the provisions of PT. That means, should be, all political parties participating in the legislative elections have the right (so that they are free) to carry their own presidential/vice presidential candidate pairs. In another sense, if the basis is presidentialism, then the regulation regarding the requirements for the support of a presidential/vice presidential candidate by a political party is to pay more attention to the figure or figure of the candidate to be 
promoted, not the political party that supports it. ${ }^{55}$ In the end, it needs to be realized that all existing government systems have both advantages and disadvantages. The principle of presidentialism clearly contains weaknesses, but once the choice is taken care of, it must be followed by a consistent attitude, not ambiguous as the MK opinion. In presidentialism, there is only one official from a presidential position who is filled by direct election by the people. Therefore, the success of presidentialism does not depend entirely on the normative system, but also depends on the personal figure of the president (because there is only one president). The implementation of the principle of presidentialism "purely and consequently" is highly dependent on the personal character of the governing president, and this is an inherent weakness of presidentialism. In practice, In both the era of President Susilo Bambang Yudhoyono and President Joko Widodo, the support of political parties in parliament was considered a very important variable for the success of his government. These two figures tend to choose to play it safe by promoting "very accommodating" politics by embracing as many political forces as possible in parliament. In our presidential practice, no president has yet dared to take "risks", in this case denying political power in parliament because of his confidence that he is "the president of the people". 56

Reflecting on the illustration above, it appears that there is a very fundamental gap between the "law" of presidentialism and the "practice" of presidentialism. Ideally, the principle of presidentialism needs a president who is able to be independent from the political forces in parliament by presenting himself as president according to presidentialism, namely the president of the people, not the president of a political party. The people's president is a promise that is inherent from the presidential system as illustrated by the philosophy. On that basis, the presidential coalition is with the people, not the oligarchic power of political parties, although political parties are also the political representation of the people in the realm of legislative power.

The discussion has provided the irrelevance of the PT in the implementation of the principles of presidentialism. The PT is not the answer for institutional obstacles in the implementation of the principle of presidentialism in Indonesia because, according to the dissenting opinion of the Constitutional Court Decision Number 53/PUU-XV/2017, it imposes part of the logic of filling executive positions in the parliamentary system into the presidential system. ${ }^{57}$ Therefore, the proper solution is to enable the implementation of the principle of presidentialism in Indonesia to be more consistent. There is a need to amend Article 6A paragraph (2) of the 1945

\footnotetext{
55 Abdul Ghoffar, "Problematika Presidential Threshold: Putusan Mahkamah Konstitusi dan Pengalaman di Negara Lain," Jurnal Konstitusi, Vol. 15, Issue 3, 2018, p. 497.

56 For studies related to the personal character of the president (in this case President Susilo Bambang Yudhoyono) and the effectiveness of the application of the principle of presidentialism in a multi-party system, see in Hanta Yudha AR, Presidensialisme Setengah Hati: Dari Dilema ke Kompromi, Jakarta: PT Gramedia Pustaka Utama, 2010.

57 See discussion $\mathrm{C}$.
} 
Constitution to eliminate the provisions that guarantee the monopoly of political parties in presidential and vice-presidential nomination to open the possibilities of independent candidates. The principles of presidentialism open such possibilities because, according to Skach's opinion:

"It is a system characterized by the separation of powers and a mutual independence of the executive and legislative powers. This is because the chief executive (a popularly elected president) and the legislature are elected independently of each other, for fixed terms of office, and both can survive for their respective terms without the other's approval." ${ }^{58}$

If the principle of presidentialism is to be implemented consistently, the above sense must be reflected in the constitution. Therefore, the independent candidates of president and vice president are logically interrelated to the principle of presidentialism. Such nomination must be accommodated by the constitution. The purity of the implementation of presidentialism principles is the basic commitment of presidentialism on the separation of legislative and executive powers. A presidential election in which the people elect their president directly means, to restate Rose-Ackerman (et. al), "to select a person who can operate as a strong manager independent of the legislature, and who can concentrate on administering the law fairly and competently." Based on the essential of presidential power, minority political parties support is not an institutional obstacle for president. President cannot be "fired" easily. Furthermore, the issue of support in parliament cannot be given a solution in the phase before presidential election but also in the phase after presidential election. Elected president is a significant political attraction because the president has a broad range of powers in executive realm.

Therefore, instead of inspiring the Constitutional Court's opinion, Linz's opinion needs a proper solution. Indonesia must commit to the consistent implementation of presidentialism. Linz found the failure of the practice of presidentialism in Latin America, which is commonly called dual legitimacy, where in the end these countries became authoritarian. ${ }^{59}$ Presidentialism is difficult to build a compromise if there is a situation where a strong president faces majority of parliamentary political forces. ${ }^{60}$ Therefore, presidentialism could face dangers when it found a president who had the expertise to exploit a populist agenda to create a

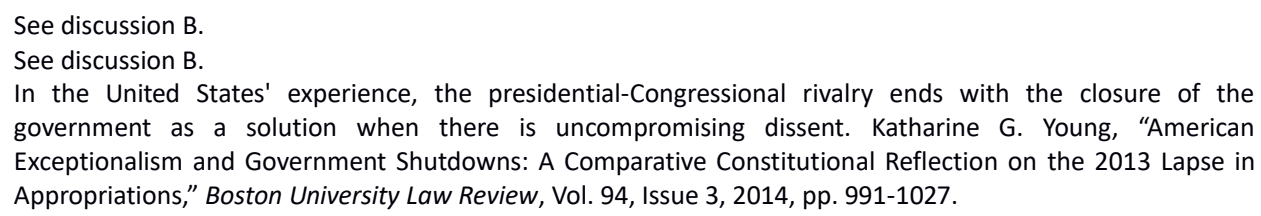
government as a solution when there is uncompromising dissent. Katharine G. Young, "American Exceptionalism and Government Shutdowns: A Comparative Constitutional Reflection on the 2013 Lapse in Appropriations," Boston University Law Review, Vol. 94, Issue 3, 2014, pp. 991-1027. 
dictatorship. This is the reason for the failure of presidentialism in Latin America because, in contests with presidents, parliaments are powerless and defeated. It is not about a president who manages to gain majority support in parliament.

\section{E. Conclusion}

This study concludes that the issue of the PT's constitutionality has a solution in the dissenting opinion of the Constitutional Court Decision Number 53/PUU-XV/2017 that the PT imposes part of the logic of filling executive positions in the parliamentary system into the presidential system. Presidentialism with PT is no longer true presidentialism. This contradicts the commitment to purify the implementation of presidentialism in Indonesia as explicitly stated as one of the points of political policy in the amendments to the 1945 Constitution. By no longer giving monopolistic power to political parties as the bearers of the presidential and vice-presidential candidate pairs, including by accommodating the possibility of pairs of presidential and vice-presidential candidates outside the political party line. With such constitutional provisions, the existence of PT will automatically collapse.

\section{References}

\section{Books}

Ávila, Humberto, Theory of Legal Principles, Springer, Dordrecht, 2007.

Bailey, Jeremy D., Thomas Jefferson and Executive Power, Cambridge University Press, Cambridge, 2007.

Cheibub, Jose Antonio, Presidentialism, Parliamentarianism and Democracy, Cambridge University Press, Cambridge, 2007.

Cheibub, Jose Antonio, and Fernando Limongi, "Legislative - Executive Relations" in Tom Ginsburg and Rosalind Dixon (eds.), Comparative Constitutional Law: Research Handbooks in Comparative Law, Edward Elgar Publishing, Cheltenham-UK \& Northampton-USA, 2011.

Hanta Yudha AR, Presidensialisme Setengah Hati: Dari Dilema ke Kompromi, PT Gramedia Pustaka Utama, Jakarta, 2010.

Holmes, Oliver Wendell, The Common Law, Harvard University Press, CambridgeMassachusetts, 2009.

Lijphart, Arend, Patterns of Democracy: Government Forms and Performance in Thirty-Six Countries, Yale University Press, New Haven-Connecticut, 2012.

Suwoto Mulyosudarmo, Peralihan Kekuasaan: Kajian Teoretis dan Yuridis terhadap Pidato Nawaksara, PT Gramedia Pustaka Utama, Jakarta, 1997.

\section{Other Documents}

Abdul Ghoffar, "Problematika Presidential Threshold: Putusan Mahkamah Konstitusi dan Pengalaman di Negara Lain," Jurnal Konstitusi, Vol. 15, Issue 3, 2018.

Ackerman, Bruce, "The New Separation of Powers," Harvard Law Review, Vol. 113, Issue 3, 2000. 
Calabresi, Steven G., "The Virtues of Presidential Government: Why Professor Ackerman is Wrong to Prefer the German to the U.S. Constitution," Constitutional Commentary, Vol. 18, Issue 1, 2001.

Gerring, John, Strom C. Thacker and Carola Moreno, "Are Parliamentary Systems Better?", Comparative Political Studies, Vol. 42, Issue 3, 2009.

Linz, Juan J., "The Perils of Presidentialism," Journal of Democracy, Vol. 1, Issue 1, 1990.

Mainwaring, Scott, and Matthew S. Shugart, "Juan Linz, Presidentialism and Democracy," Comparative Politics, Vol. 29, Issue 4, 1997.

Rose-Ackerman, Susan, Diane A. Desierto and Natalia Volosin, "HyperPresidentialism: Separation of Powers without Checks and Balances in Argentina and the Philippines," Berkeley Journal of International Law, Vol. 29, Issue 1, 2011.

Skach, Cindy, "The 'Newest' of Separation of Powers: Semipresidentialism," International Journal of Constitutional Law, Vol. 5, Issue 1, 2007.

Sunstein, Cass R., "Problems with Rules," California Law Review, Vol. 83, Issue 4, 1995.

Young, Katharine G., "American Exceptionalism and Government Shutdowns: A Comparative Constitutional Reflection on the 2013 Lapse in Appropriations," Boston University Law Review, Vol. 94, Issue 3, 2014.

\section{Legal Documents}

The 1945 Constitution of the Republic of Indonesia [Undang-Undang Dasar Negara Republik Indonesia Tahun 1945].

The Law Number 7 of 2017 on General Elections [Undang-Undang Nomor 7 Tahun 2017 tentang Pemilihan Umum].

The Constitutional Court Decision Number 51-52-59/PUU-VI/2008 [Putusan MK Nomor 51-52-59/PUU-VI/2008].

The Constitutional Court Decision Number 14/PUU-XI/2013 [Putusan MK Nomor 14/PUU-XI/2013].

The Constitutional Court Decision Number 53/PUU-XV/2017 [Putusan MK Nomor 53/PUU-XV/2017].

The Constitutional Court Decision Number 49/PUU-XVI/2018 [Putusan MK Nomor 49/PUU-XVI/2018]. 